\title{
In memoriam of Prof. Antonio Lauria
}

Professor Antonio Lauria peacefully passed away at his country house, in Olgiate Molgora, in Italy, on June 19, 2020. He is survived by his spouse, Elena and his two sons, Alessandro and Federico.

As his alumni, we are glad to remember him in this journal because, throughout his long scientific career, he always maintained a "histochemical vision" in all the researches he has been dealing with. Moreover, he was a member of the editorial board of the European Journal of Histochemistry since the eighties of the last Century, and a very active fellow of the Italian Society of Histochemistry for which he served as Secretary from 1982 to 2009 . In this role, thanks to his natural enthusiasm and ability to humanly and scientifically co-operate with colleagues, he was involved in organizing numerous conferences of high scientific value, where histochemists had the great opportunity to

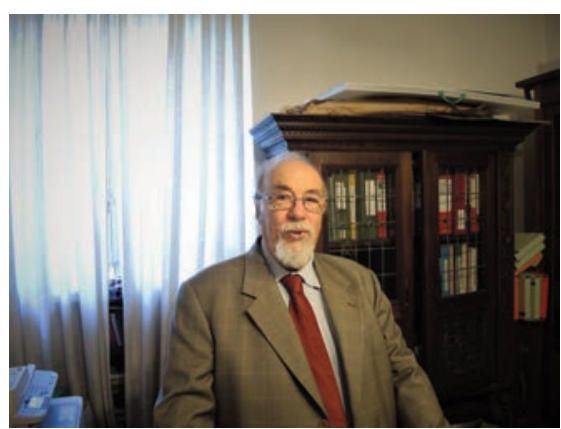
meet and know each other personally.

Professor Antonio Lauria graduated in Veterinary Medicine in 1963, from the University of Milan, and soon after went to work on vaccine production for a pharm industry. However, his great passion for research brought him back to his Alma Mater where he became full professor of Anatomy and Embryology. The first steps of his scientific career were under the guide of Prof. Carlo Bignardi, outstanding pioneer in histochemistry, and of his first disciple, Prof. Giuseppe Aureli. With them he studied the problem of the so called "special serous" exocrine secretions; when still a student, following his natural curiosity, vivacity and inclination towards the experimentation of new technologies, he approached the study of mucopolysaccharides in the connective tissue, combining the classic histochemical protocols with the emerging electron microscopy techniques. At the same time, he applied enzyme histochemistry and histo-spectrophotometry to study the evolution of testis interstitial cells from foetal to adult age in the equids, and used autoradiography histochemical protocols to evaluate the expression of ovary gonadotropins receptors in domestic and laboratories species. Prof. Lauria was also one of the pioneers of mammalian tissue culture.

These studies and the friendship with Prof. Telesforo Buonadonna, who founded the International Congress of Animal Reproduction (ICAR), opened the way to the line of research to which he devoted most of his life as a scientist and professor: reproduction in farm animals. With his colleague and friend, Professor Olivo Oliva he pioneered superovulation, embryo transfer and cryopreservation, and founded the Italian Society for Embryo Transfer. Their studies were also instrumental to the development and registration of a particular gonadotropin preparation, now largely used worldwide to induce superovulation in cattle.

Prof. Lauria believed that both basic and applied research and, at the same time, the experience of practitioner were necessary to improve results in embryo production and transfer, and with this spirit he founded a group that soon became the scientific reference point for veterinarian, farmer and breeders' association.

He was an outstanding mentor: in his laboratory many Italian reproductive biologists moved their first steps, keeping high the tradition of the Milan Veterinary School of which he was a proud, enthusiastic and inspiring leader for many years.

With his group, he developed a particular system for in vitro culture of pre-antral follicles, and investigated the role of spermatozoa as DNA vectors for the creation of transgenic animals. He also studied the molecular mechanisms involved in oocyte maturation and in the early stages of embryonic development, applying his deep experience in histochemistry, electron microscopy and tissue culture and his knowledge in histology and embryology, without ever forgetting his veterinary education.

He was member of numerous scientific Societies and received several awards for his scientific activities culminating in 1993 with a Degree Honoris Causa in Animal Science from the Jagiellonian University in Krakow, Poland.

For his top-level works and human qualities, in 1998 Prof. Bonadonna recommended him as his successor as the Italian representative in the ICAR Standing Committee. Since then, Prof. Lauria has passionately been working to support ICAR activities and ideals that he fully embraced, dedicating his efforts to support scientists in science as well as in their daily life in different countries such as Poland and Ethiopia.

Speaking of Prof. Lauria, we cannot forget his private side, which once again testifies his liveliness and eclecticism: he had many hobbies and abilities that absorbed him completely after he retired, in 2008. This included writing poems in Milanese dialect, growing cactus, flowers, and fruit trees in his country house "I Vallicelli". Fruit production was so large that, with his wife Elena, he set up an artisan production of high-quality jams. He was also a skilful blacksmith making decorations and artworks with wrought iron. "I Vallicelli" was always open to friends, visiting scientists and past students, with the unforgivable cakes prepared by Elena, his life partner for more than 60 years.

Our touched thoughts are for Professor Lauria's family. 